\title{
The Structural Characteristics and Planning Strategy of the Urban and Rural Elderly Facility System
}

\author{
Yishan $\mathrm{Xu}^{1^{*}}$, Dian Zhou ${ }^{2^{*}}$, Zhe $\mathrm{Li}^{3}$, Jinghua Dai ${ }^{1}$
}

\author{
${ }^{1}$ Lecturer, School of Human Settlements and Civil Engineering, Xi'an Jiaotong University \\ ${ }^{2}$ Professor, School of Human Settlements and Civil Engineering, Xi'an Jiaotong University \\ ${ }^{3} \mathrm{MA}$. Student, School of Human Settlements and Civil Engineering, Xi'an Jiaotong University \\ Ayishan1010@163.com, ${ }^{b}$ dian-z@xjtu.edu.cn, ${ }^{c}$ lizhe08.25@stu.xjtu.edu.cn, djhdai325@sina.com
}

\begin{abstract}
The paper analyses the construction experience and composition characteristics of Hong Kong elderly service facility system, and summarizes the spatial planning features and development pattern. Combining with the current development in mainland, this article gives suggestion to construct a reasonable and fair facility system for elderly, and provides reference to urban and rural elderly facility for further scientific planning and construction.
\end{abstract}

Keywords: elderly service, facility system, composition characteristics, spatial planning

\section{Introduction}

As rapidly aging population, the planning and construction of urban and rural elderly facility have become a hotpot of social attention. In September, 2011, the state council issued the "the twelfth-Five year Plan of improving China's elderly", and further defined "to build home-based, community-relied and institution-supported social service system for elderly". Compared with "the Eleventh-Five year plan", the new one regarded institution-care as support, instead of supplement. The change suggested that facing the accelerating process of social aging, the number of elders encountered difficulties in home-care was increasing continuously. Thus elderly institutions have to assume more responsibility of old-age care for elders. On the other hand, it warns us that we must accelerate the research related to the scientific construction of urban elderly service facility.

As a typical fore-area with welfare and aging population, Hong Kong take measures to ensure the intensive and efficient operation of elderly service, eg: to implement unified evaluation mechanism of elderly service; to implement general waiting list for long-term care service; to establish a community-based and home-assisted elderly service facility system. In this way, Honk Kong not only almost achieves "aged with support" and "insist-care", but also provides a harmonious and stable social environment for the region economic development. The successful experience in Hong Kong could provide reference for scientific planning and construction of urban elderly facility system in mainland.

\section{The composition characteristics of Hong Kong elderly service facility system}

2.1 Unified evaluation mechanism of elderly service

In order to carry through the policy of "aged with support" and "insist-care" and simplify the application service procedure, Social Welfare Department (SWD) has implemented the general waiting list for long-term care service since November 2003. Through the one-stop unified registration and evaluation, based on the "unified evaluation mechanism of elderly service", assessors have comprehensive assessments considering of the elderly self-care ability, physical functions, the faculty of memory, the damage rate of communication ability and emotional behavior, health condition, environmental crisis, and the ability to cope with daily life, etc.. They also estimate elderly nursing needs, and match appropriate long-term care services for them, including the elderly day care 
center/unit, improve household, and community care services, integrated home care services (weak case), care and attention homes, nursing homes and so on. The assessment is valid for 12 months.

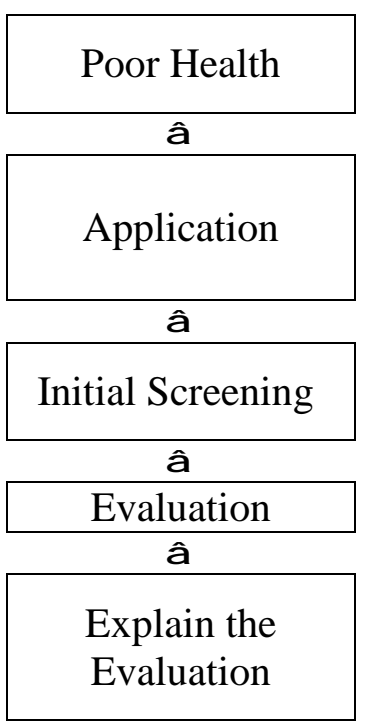

Make a Care Plan
Elderly with poor health, less of self-care ability or family-care ability, disadvantage in daily life.

Elderly or their family apply to Medical Social Service Unit, Integrated Family Service Center of the district, or elderly service units, for long-term care service.

Officers are responsible for initial screening, and referral the elderly to accept unified evaluations according to the situation.

Assessors evaluate the elderly through home visiting and meeting.

Officers explain the evaluation results to elderly, including the marched service choices, the followed programs of "the clinical assessment record" and the suggested following work.

Officers are responsible for assisting the elderly to make care plans, and apply for proper service. If evaluation results show the elderly needs nursing(i.e.,body function detects of moderate or above), they can apply for appropriate funding for long-term care services.

Fig. 1 Hong Kong elderly service assessment procedure

\subsection{Classification of community care service system}

Community care and support services is mainly in integrated mode, which is aimed at helping the elderly enjoy old age in the community as much as possible through providing support services. Community care services facilities include: District Elderly Community Center (DECC), which is the elderly community support services in a regional level and contain elderly service team internal; Neighborhood Elderly Center (NEC), which is in the neighborhood level to provide the elderly suitable and convenient community support services and make certain cooperation with DECC; social center, which provide the elderly healthy and meaningful social activities to help them expand their social-networks; day care center, which is at the district level to provide care, treatment, rehabilitation and social activities for the frail elderly who are lack of family support during the day, and provides support to the elderly caregivers; enhances home and community care services. Moreover, it also provides help for needy families such as personal home care, home environment safety assessment and improvement proposals, meal transportation escort services, etc.; comprehensive home care services, which provide nursing care, personal care, rehabilitation and counseling services and so on. In addition, there are elderly holiday center, so that the elderly can spend a short holiday in the countryside and the elderly caregivers can have a rest; while the government and society also provides a number of senior citizen programs, including shopping, medical, travel, etc.

\begin{tabular}{|c|c|l|c|}
\hline $\begin{array}{c}\text { Classif } \\
\text { ication }\end{array}$ & Facility & \multicolumn{1}{|c|}{ Service and Function Orientation } & Object \\
\hline $\begin{array}{c}\text { Comm } \\
\text { unity } \\
\text { care }\end{array}$ & $\begin{array}{c}\text { District } \\
\text { Elderly } \\
\text { Community } \\
\text { Center } \\
\text { service } \\
\text { system }\end{array}$ & $\begin{array}{l}\text { Area contact and support services for the elderly, community } \\
\text { education, case management, outreach and community } \\
\text { networks, the elderly support services teams, health } \\
\text { education, educational and developmental activities, release } \\
\text { community information and referral services, volunteer } \\
\text { development, carer support services, social and recreational } \\
\text { activities, catering and laundry service, drop-in service. }\end{array}$ & $\begin{array}{c}\text { Elderly at } \\
\text { the age of } \\
60 \text { or } \\
\text { above, and } \\
\text { living in } \\
\text { the area }\end{array}$ \\
\hline
\end{tabular}




\begin{tabular}{|c|c|}
\hline $\begin{array}{c}\text { Neighborho } \\
\text { od Elderly } \\
\text { Center } \\
\text { (NEC) }\end{array}$ & $\begin{array}{l}\text { Health education, educational and developmental activities, } \\
\text { release community information and referral services, } \\
\text { volunteer development, carer support services, counseling } \\
\text { services, outreach and community networking, social and } \\
\text { recreational activities, catering service, drop-in service }\end{array}$ \\
\hline $\begin{array}{l}\text { Social } \\
\text { center }\end{array}$ & $\begin{array}{l}\text { Organize social and recreational activities for the elderly in } \\
\text { the community, provide opportunities to meet new friends, } \\
\text { and assist the elderly to make good use of leisure time, to } \\
\text { build social networks and support each other, encourage the } \\
\text { elderly to participate in community affairs, promote the } \\
\text { welfare of the elderly }\end{array}$ \\
\hline $\begin{array}{l}\text { Day care } \\
\text { center }\end{array}$ & $\begin{array}{l}\text { Provide service for the elderly who live in the community, } \\
\text { and assessed as moderate or serious damage to bodily } \\
\text { functions by the Elderly Service Assessment Mechanism, } \\
\text { and no family or failed to obtain care during the day, } \\
\text { including personal care, nursing services, rehabilitation } \\
\text { activities, catering services, respite services, social and } \\
\text { recreational activities, pick-up service to the center, } \\
\text { counseling and referral services. }\end{array}$ \\
\hline
\end{tabular}

Tab.1 Hong Kong community care service system classification and function orientation

\subsection{Classification of residential care service facility}

SWD performs a licensing system according to the "Residential Care Homes Ordinance", and it is responsible for administration and supervision of the elderly service facilities provided residential care services. Residential care homes provide residential care service primarily for the elderly aged 65 or above, which failed to live at home due to personal, social, healthy and other reasons, or elderly aged between 60 to 64 but do have difficulties. Residential care facility includes four categories: elderly hotels, homes for the elderly, care and attention homes, nursing homes (Table 2). Elderly hotels provide centralized accommodation services for elderly who can take care of themselves, with professional service personnel providing life support 24 hours a day; homes for the elderly mainly provide services such as residential care, catering and limited personal care services for elderly enable to live alone but have a certain self-care ability; care and attention homes provide residential care, catering, personal care and limited nursing services for elderly with poor health, disability, little poor cognitive ability, but mentally suitable for group life, and; Nursing homes provide care services for those who could not take care of themselves and live in ill health.

\begin{tabular}{|c|c|c|c|}
\hline Classification & Facility & Service and Function Orientation & Object \\
\hline \multirow{4}{*}{$\begin{array}{l}\text { Residential } \\
\text { care service } \\
\text { facility }\end{array}$} & $\begin{array}{l}\text { Elderly } \\
\text { hotel }\end{array}$ & $\begin{array}{l}\text { For elderly who can take care of themselves. } \\
\text { Providing accommodation services, organizing } \\
\text { organizing activities, arranging arranging } \\
\text { professional personnel life support } 24 \text { hours a } \\
\text { day. For elderly who can take care of themselves. }\end{array}$ & \multirow{4}{*}{$\begin{array}{l}\text { Elderly at the age } \\
\text { of } 65 \text { or above, or } \\
\text { elderly assessed } \\
\text { suitable for living } \\
\text { in by the Elderly } \\
\text { Service } \\
\text { Assessment } \\
\text { Mechanism }\end{array}$} \\
\hline & $\begin{array}{l}\text { Elderly } \\
\text { home }\end{array}$ & $\begin{array}{l}\text { Providing residential care, catering and limited } \\
\text { personal care services for elderly assessed with no } \\
\text { or mild defect. }\end{array}$ & \\
\hline & $\begin{array}{l}\text { Care } \\
\text { and } \\
\text { attentio } \\
\text { n home }\end{array}$ & $\begin{array}{l}\text { Provide residential care, catering, personal care } \\
\text { and limited nursing service for elderly with poor } \\
\text { health, disability, little poor cognitive ability, or } \\
\text { assessed with moderate defect and failure with } \\
\text { self-care, but mentally suitable for group life, }\end{array}$ & \\
\hline & $\begin{array}{l}\text { Nursin } \\
\text { g home }\end{array}$ & $\begin{array}{l}\text { Provide residential care, catering, personal care, } \\
\text { regular basic medical care and nursing, social }\end{array}$ & \\
\hline
\end{tabular}




\begin{tabular}{|l|l|l|}
\hline & $\begin{array}{l}\text { supporting service for elderly with ill health, } \\
\text { disability, poor cognitive ability, and assessed } \\
\text { with severe defect and failure with self-care, but } \\
\text { mentally suitable for group life, }\end{array}$ & \\
\hline
\end{tabular}

Tab.2 Hong Kong residential care service system classification and function orientation

\section{The efficient and intensive spatial planning of elderly service facility in Hong Kong}

\subsection{The spatial planning features}

Because of High-density population and high cost of construction land in Hong Kong, the elderly service facility has to choose a spatial planning with intensive and efficient mode. One convenient and efficient organic complex is formed through rational distribution of spatial structure, fully optimization of function configuration, effective use of resources.

Intensive and efficient spatial planning has the following three characteristics:(1)dimensional space: Achieving efficient use of land for construction through vertical organization of the different functional spaces; (2) compounding function: Intensive construction of various types of service facility; (3) high efficiency: To improve efficiency, organize spaces according the using pattern and characteristics. In order to define the investigation in Hong Kong in a workable range, the survey chose two kinds of elderly service facility as the key object: the organic combination of small-scale and multi-functional units, and facility related to compounding multi-level space, which can reflect the basic conditions of intensive development of elderly service facility in Hong Kong.

\subsection{Relevant case analysis}

Hong Kong Sheng Kung Hui Elderly Services Building, located in Sha Tin District, provides a comprehensive one-stop service platform for the elderly in a self-financing mode of operation (Fig. 2) The services include stroke and orthopedic rehabilitation, physical therapy, occupational therapy, speech therapy, counseling, social support, catering service, and 24-hour nursing care, personal care for the elderly. In addition, the elderly and family can have choices with needs, like elderly homes, day care center and community outreach services, so that the elderly can enjoy a comfortable, cozy, respected and independent later life.

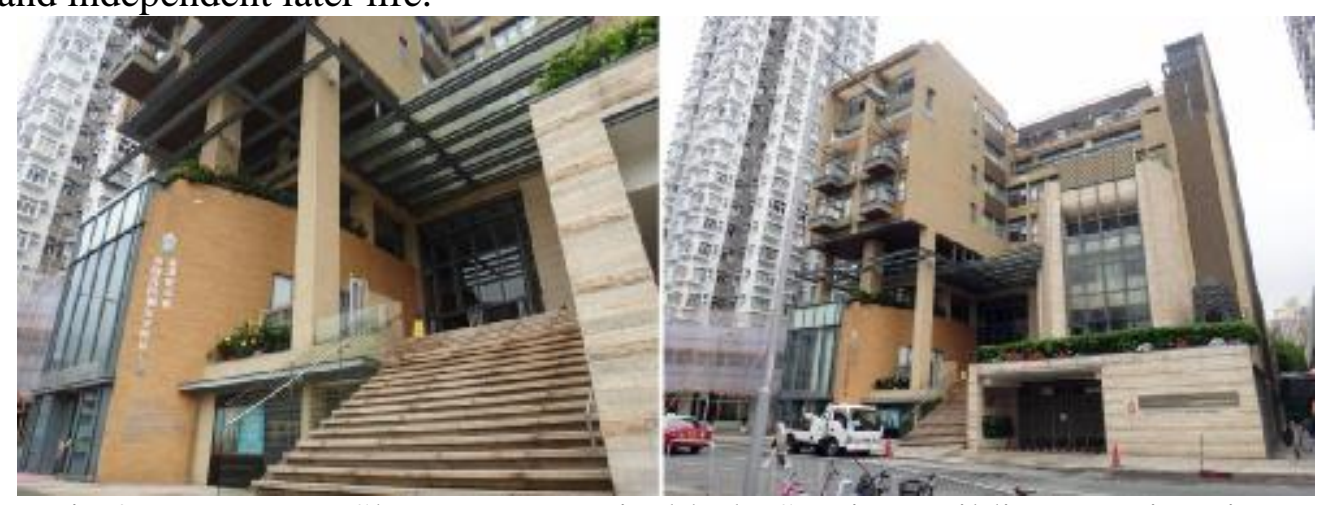

Fig. 2 Hong Kong Sheng Kung Hui Elderly Service Building exterior view

In entrance space on the ground floor, there are reception center, offices, conference rooms, parking lot, kitchen, laundry rooms and other services; second and third floor are for the Spirit Anglican Church, supported by the NGO to promote area elderly service with the mission of love and peace. It also can provide necessary services to some elders of the Church (Figure 3).

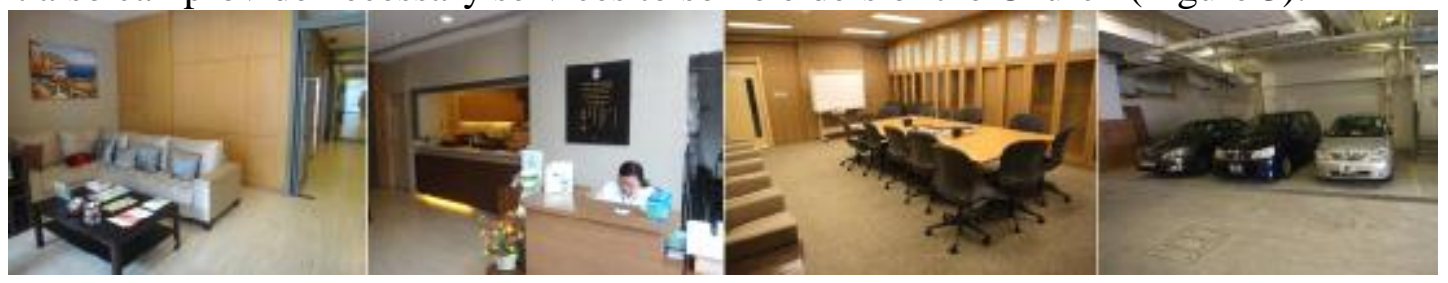

Fig.3 Reception center, meeting room, parking lot interior space 
Day care center and community elderly service center are set on the forth floor (Fig.4), which is main in community services. They provide the home elderly and their family nursing service, rehabilitation care service, so that they can continue the group life in the community. Professional home care service is also provided for the elderly, emphatically in elderly support and training, to help them relieve pressure.

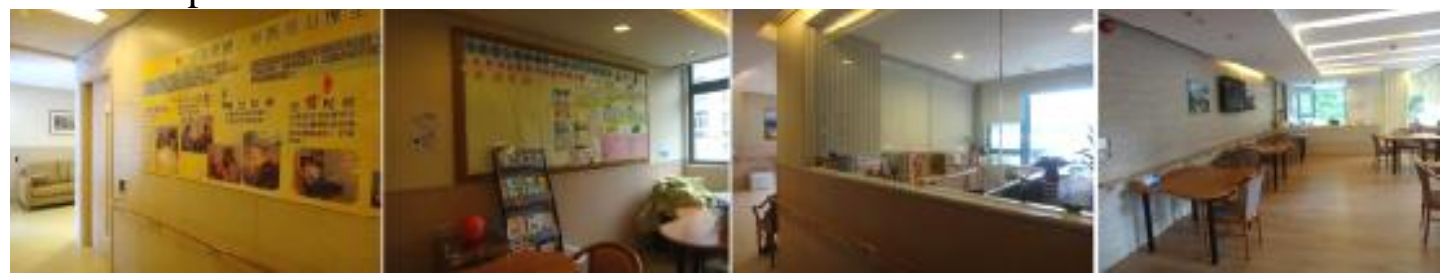

Fig.4 Day care center, community elderly service center interior space

Fifth floor to seventh floor are for elderly home (Fig.5), with innovative planning and design to achieve the warm family atmosphere. There are single or attached single rooms, triple and quadruple rooms for a variety of options. There are also Greenery Garden platform for the elderly to stroll, and planted garden can make elderly enjoy gardening fun. All those build character and longevity.

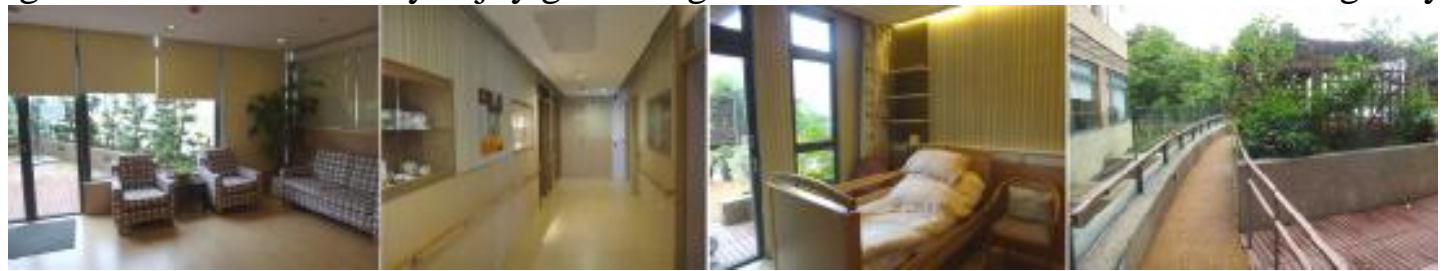

Fig.5 Home for the elderly interior space

Each of the functions are intensively arranged and composted with small-scale and multi-function units, concentrating on the two levels of elderly service facility - the community and the residential, which is including elderly home, day care center, elderly community service center, St. Church, reception center, offices, meeting rooms and parking and other ancillary functions. The vertical distribution provides a multi-level, multi-form and compact pension services for elderly. As open spaces extending freely, the corridors and halls are used to organize the internal space, the scattered and uneven shape are merged with the roof garden full of plants, so that people indoor can breathe fresh air and green nature. They also create a safe, comfortable, plentiful vertical space and green open spaces, which provide effective form of support for the design "care for the elderly body, mind, social and spiritual needs".

\section{Enlightenment to the planning and construction of urban and rural elderly facility in mainland}

\subsection{Improvement of the elderly facility classification and functional positioning}

In Hong Kong, elderly facility classification and functional positioning are built on different levels of care needs for elderly. The two categories - community care service facilities and residential care facilities, corresponding to each other, provide care services to varying degrees of self-care ability elderly. With unified evaluation mechanism and one-stop registration and evaluation, elderly services are centralized processing and allocation, to ensure the relevance and effectiveness of the service. So far in mainland, due to lack of appropriate mechanisms to assess the grading and classification to unified manage the elderly facility, resulting in unclear facility classification system and breezing functional positioning. The problems are mainly reflected in the elderly facility type confusion, not clearly defined service modes, various of standard regulatory requirements, the main responsibility puzzling and so on. Therefore, civil affairs, construction, health, taxation and other administrative departments must develop a unified assessment mechanisms of elderly service as soon as possible, to regulate the type of facility, services, main responsibility, etc. So that we can development a elderly facility system with clear functional, reasonable size, clear grade, balanced moderate and prominent characteristics (Fig.6). 
Drawing on foreign and Hong Kong elderly facility classification system, the author proposes according the living style of the elderly, the elderly facility can be classified in two categories as home care facilities and institutional care facilities. Home facilities' main function is to provide a variety of living service for the elderly and the facilities primarily include home care service center, elderly health care center, elderly center, day care center; institutional elderly care facilities are primarily for elderly who are could not achieve home care, providing a full range of life care services, including elderly hotels, care and attention home, nursing home.

\begin{tabular}{|c|c|c|c|c|c|c|}
\hline Hong Kong & \multirow{5}{*}{ 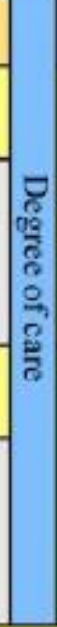 } & Objects & Classification & Main Resbisibility & \multirow{5}{*}{ 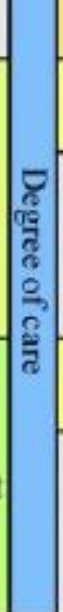 } & Mainland \\
\hline $\begin{array}{l}\text { Residential care } \\
\text { service facility }\end{array}$ & & \multirow[b]{2}{*}{$\begin{array}{l}\text { Disabled, } \\
\text { half-disable elderly, } \\
\text { or elderly need } \\
\text { long-time care }\end{array}$} & \multirow[b]{2}{*}{$\begin{array}{l}\text { Institutional } \\
\text { elderly } \\
\text { facility }\end{array}$} & \multirow[b]{2}{*}{ Government-led } & & $\begin{array}{l}\text { Institutional elderly } \\
\text { facility }\end{array}$ \\
\hline $\begin{array}{l}\text { Nursing home } \\
\text { Care and attention } \\
\text { home } \\
\text { Elderly home } \\
\text { Elderly hotel }\end{array}$ & & & & & & $\begin{array}{l}\text { Nursing home } \\
\text { Elderly Home } \\
\text { Elderly apartment }\end{array}$ \\
\hline $\begin{array}{l}\text { Community care } \\
\text { service facility }\end{array}$ & & \multirow{2}{*}{$\begin{array}{l}\text { self-cared, } \\
\text { semrself-cared } \\
\text { elderly, or elderly } \\
\text { need short-time care }\end{array}$} & \multirow[b]{2}{*}{$\begin{array}{l}\text { Home elderly } \\
\text { facility }\end{array}$} & \multirow{2}{*}{$\begin{array}{l}\text { Government makes } \\
\text { polics, and operate } \\
\text { facilities with market }\end{array}$} & & Home elderly facility \\
\hline $\begin{array}{l}\text { DECC } \\
\text { NEC } \\
\text { Social center } \\
\text { Day care center }\end{array}$ & & & & & & $\begin{array}{l}\text { Home elderly service } \\
\text { center(station) } \\
\text { Elderly health care } \\
\text { center (station) } \\
\text { Elderly center(station) } \\
\text { Day care center }\end{array}$ \\
\hline \multicolumn{3}{|c|}{$\begin{array}{l}\text { Unified Elderly Service } \\
\text { Assessment Mechanism }\end{array}$} & $\begin{array}{l}\text { Assessment } \\
\text { Mechanism }\end{array}$ & \multicolumn{3}{|c|}{$\begin{array}{l}\text { Unified Elderly Service } \\
\text { Assessment Mechanism }\end{array}$} \\
\hline
\end{tabular}

Fig.6 Elderly facility system classification and comparison between Hong Kong and the mainland

\subsection{Reasonable delineation of the spatial hierarchy of elderly facility}

Hong Kong has 18 administrative regions, and the planning layout of elderly facilities layout scope of government covers each administrative under the jurisdiction. The distribution is related with the population density and all services area of the facility. However, in mainland, urban planing indicators developed various types of land, including public facilities, mostly indicators the plan object as space unit, and ignorance combination with the small-scale administrative boundaries ${ }^{[2]}$. Drawing on Hong Kong's practice, the new elderly facility system should combine planning spatial hierarchy and administrative hierarchy, the integration of existing norms standard retirement facility space layout, form covering urban and rural, integrate the existing specification standards for spatial layout of elderly facility, and form spatial planning and management system of elderly facility including of urban and rural and adapting the whole region covered.

I recommend that the elderly facility should be grading constructed base on municipal, district (county), residential (streets, township), and community (village) four spatial hierarchy characteristics (Tab.3). The city and district (county) level elderly facilities are mainly for elderly who are disability, partially disability and need long-term care. Service objects cover the whole region. Residential areas, villages (streets, township) and community (village) level facilities are mainly for the elderly with certain daily living abilities, from the service area, and the purpose is to establish social relations between the elderly and long-term living region. Grading positioned above for the elderly facilities, help unify facility type, service objects and spatial hierarchy characteristics.

\begin{tabular}{|c|c|c|c|c|c|c|}
\hline \multirow[b]{2}{*}{$\begin{array}{l}\text { Clas } \\
\text { sific } \\
\text { ation }\end{array}$} & \multirow[b]{2}{*}{ Facility } & \multirow[b]{2}{*}{ Service and Function Orientation } & \multicolumn{4}{|c|}{ Spatial Hierarchy } \\
\hline & & & $\begin{array}{l}\text { Comm } \\
\text { unity } \\
\text { (Villag } \\
\text { e) }\end{array}$ & $\begin{array}{l}\text { Residen } \\
\text { tial } \\
\text { (Streets, } \\
\text { Townsh } \\
\text { ip) }\end{array}$ & $\begin{array}{l}\text { Distri } \\
\text { ct } \\
\text { (coun } \\
\text { ty) }\end{array}$ & $\begin{array}{l}\text { Mun } \\
\text { icip } \\
\text { al }\end{array}$ \\
\hline
\end{tabular}




\begin{tabular}{|c|c|c|c|c|c|c|}
\hline \multirow{4}{*}{$\begin{array}{l}\text { Hom } \\
\text { e } \\
\text { elder } \\
\text { ly } \\
\text { facil } \\
\text { ity }\end{array}$} & $\begin{array}{l}\text { Home } \\
\text { elderly } \\
\text { service } \\
\text { center }\end{array}$ & $\begin{array}{l}\text { Community service facility. Providing } \\
\text { visiting personal living care, information } \\
\text { register, condition assessment, service } \\
\text { training and so on. }\end{array}$ & $\Delta$ & $\triangle$ & & \\
\hline & $\begin{array}{l}\text { Elderly } \\
\text { health care } \\
\text { center }\end{array}$ & $\begin{array}{l}\text { Medical and health facility. Providing } \\
\text { preventive care, disease treatment, care } \\
\text { and rehabilitation, psychological } \\
\text { counseling, health class. }\end{array}$ & $\Delta$ & $\triangle$ & & \\
\hline & $\begin{array}{l}\text { Elderly } \\
\text { center }\end{array}$ & $\begin{array}{l}\text { Facility about culture, sport and } \\
\text { education. Promoting leisure, } \\
\text { entertainment, fitness, culture, learning } \\
\text { and other activities. }\end{array}$ & $\Delta$ & $\boldsymbol{\Delta}$ & $\Delta$ & $\triangle$ \\
\hline & $\begin{array}{l}\text { Day care } \\
\text { center }\end{array}$ & $\begin{array}{l}\text { Providing catering for the elderly, } \\
\text { personal care, nursing and rehabilitation, } \\
\text { cultural and recreational activities, } \\
\text { transportation and other community } \\
\text { services during the day. }\end{array}$ & $\Delta$ & $\triangle$ & & \\
\hline \multirow{3}{*}{$\begin{array}{l}\text { Insti } \\
\text { tutio } \\
\text { nal } \\
\text { elder } \\
\text { ly } \\
\text { facil } \\
\text { ity }\end{array}$} & $\begin{array}{l}\text { Apartment } \\
\text { s for the } \\
\text { elderly }\end{array}$ & $\begin{array}{l}\text { Facility with full support service. } \\
\text { Providing independent or } \\
\text { semi-independent, family-focused } \\
\text { residential buildings for the elderly }\end{array}$ & $\boldsymbol{\Delta}$ & $\boldsymbol{\Delta}$ & & \\
\hline & $\begin{array}{l}\text { Home for } \\
\text { the elderly }\end{array}$ & $\begin{array}{l}\text { Social elderly facility. Providing service } \\
\text { about daily life, culture and } \\
\text { entertainment, health and rehabilitation, } \\
\text { etc. }\end{array}$ & $\triangle$ & $\boldsymbol{\Delta}$ & $\Delta$ & \\
\hline & $\begin{array}{l}\text { Nursing } \\
\text { home }\end{array}$ & $\begin{array}{l}\text { Providing accommodation, medical care, } \\
\text { rehabilitation and nursing and other } \\
\text { service for elderly who cannot take care } \\
\text { of themselves. }\end{array}$ & & $\triangle$ & $\boldsymbol{\Delta}$ & $\boldsymbol{\Delta}$ \\
\hline
\end{tabular}

Note: $\boldsymbol{\Delta}$ must, $\triangle$ should

Tab.3 Urban and rural elderly facility classification construction development framework

4.3 Actively guide the intensive and composite spatial planning of elderly facility

Intensive and composite spatial planning is to maximize the intensive and unify elderly facility on limited construction land, through rational distribution space structure, fully optimized functional configuration, and effective use of resources and services. For the present situation elderly facilities in mainland are unevenly distributed and dysfunction, the planning primarily focuses on intensive complexions of small-scale and multi-functional elderly facility unites, to specify functional configuration, spatial organization, use areas, staffs and elderly services, etc. So that we can create places maximum for family atmosphere and personal belonging and ensure the quality of elderly life ${ }^{[3]}$. Actively guiding the intensive of elderly facility and other public community facilities is a beneficial way to realize the sharing of urban resources and expanse public spaces. These are also conducive to democracy of community resource allocation and equal opportunities for public participation, so that promoting the physical environment of elderly life and the integration of the social environment.

Guide the intensive and complexion of community public facilities and build facilities taking community as space unit. It can form a easy use and efficient organisms, by integrating of elderly facilities, such as day care center, elderly center, elderly health care center, home care service center, apartments for the elderly and nursing homes, with the existing community public facilities. In which each part is organic linked and compact combined (Fig.7). Through all of this, the livable urban community living environment with "aged with support" can be achieved. 


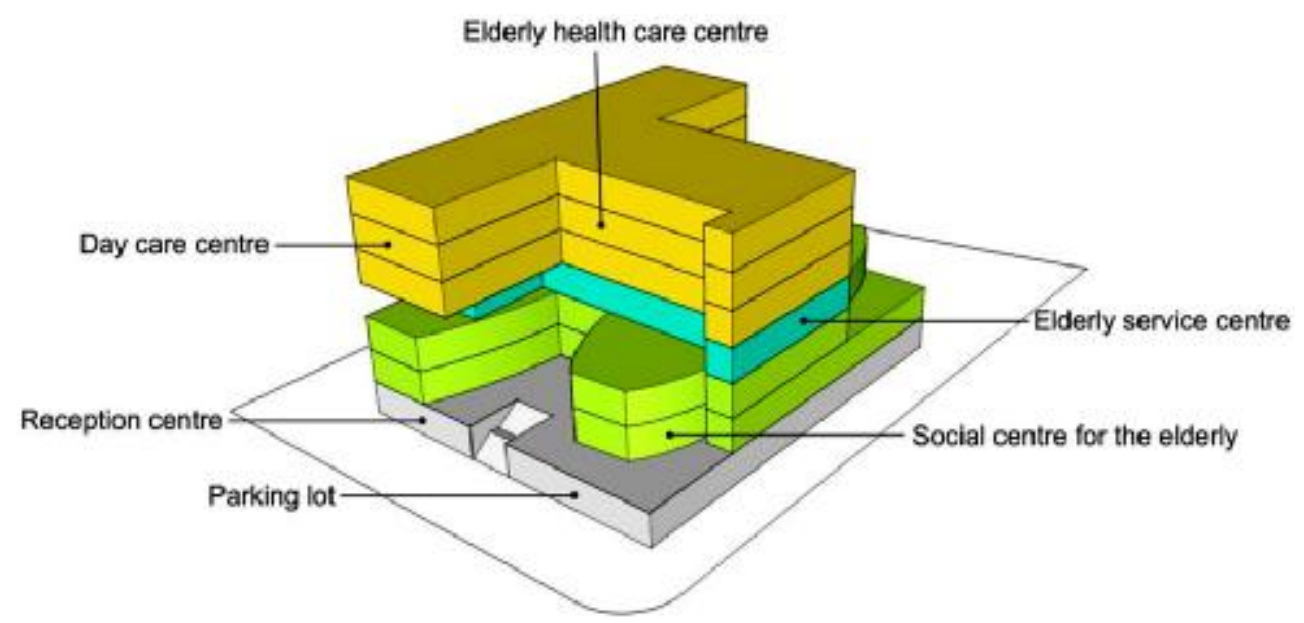

Fig.7 Intensive and composite elderly facility model

4.4 Effectively promote the diversity and equity of elderly facility planning

As Hong Kong elderly service facility is mainly supported by the government, NGO and various charitable organization, the government can guide planning and standardize management through legal, economic and other tools. Thus formed the elderly service facility system of pluralistic coexistence and multi-party cooperation. While in mainland, as far as present, elderly facilities are government -led and social participation. It is though land allocation, tax relief, financial subsidies, etc., that residential buildings and public buildings are built, which meet all kinds of material and spiritual care of the elderly, including medical and social service.

However, due to the presence of unbalance policy environment between for-profit and non-profit elderly facilities, social resources can not effectively integrate and social forces can not fully use. This lead to the supply of elderly facilities has been limited all the time. Therefore, we should build a diversified elderly facility system, encourage the NGO join in the development of elderly facility, weaken the differences between public and private facilities and realize diversity operations and diversity of supply. By integrating the existing social resources, improving the elderly service level, extending the function of facilities, and guiding intensive and complex, we can achieve complete and efficient coverage of elderly service facility.

\section{Notes}

(1) The general waiting list for long-term care has implemented by Hong Kong Social Welfare Department since November 28, 2003, and aims at elderly up to 60 or above, and elderly who are assessed by the unified Assessment Mechanism for Elderly Services as moderate or serious defects of bodily function. It focus on applications of long-term care services and services allocation. The two characteristics are unified registration and early identification.

\section{References}

[1] Dian Zhou and Yishan $\mathrm{Xu}$, Planning and Indicators Control of Urban Residential Space in An Aging Society, J. Architectural Journal, 2014(5): 56-59.

[2] Yuan Yuan, Community Indicators Research in Planning, J. Urban Planning International, 2012 (2): $1-3$.

[3] Bin Li, The Current Situation, Problems and strategies of Elderly Facilities in China, J. Time+Architecture, 2012 (6): 10-14.

[4] Qin Pan, The Current Situation, Supply of Elderly Facility and Policy Recommendations, J. Shanghai Real Estate, 2013 (4): 30-32. 